\title{
Splint Fixation with Circummandibular Wires for Pediatric Mandibular Fracture: Two Case Reports
}

\author{
Çocuklarda Mandibular Kırıkların Splint Fiksasyonu ile Tedavisi: Iki Olgu Raporu
}

Bahar SEZER Banu ÖZVERI KOYUNCU Cemal AKAY Tayfun GÜNBAY

Ege Üniversitesi, Diş Hekimliği Fakültesi, Ağız, Diş, Çene Cerrahisi AD, IZMiR

\begin{abstract}
Mandibular fractures in the pediatric population are uncommon. The conservative treatment is in most cases advocated before the use of internal rigid fixation with plates and screws because they have a negative effect on skeletal growth and unerupted teeth. Knowledge of conservative and less invasive treatment options is essential in order to minimize these potential risks. This article presents two pediatric patients who were managed acrylic splints constructed on the mandibular plaster models and fixed in place with circummandibular wires. The splints were left in place for 3 weeks and the patients were successfully treated.
\end{abstract}

Keywords: Pediatric, mandibular fracture, circummandibular wires, acrylic splint

\section{Özet}

Çocuk hastalarda mandibular kırıklara sık olarak rastlanmaz. Pek çok olguda iskeletsel gelişim ve sürmemiş dişlerin bulunması nedeniyle, plak ve vidaların kullanıldığı sert internal fiksasyon tedavisi yerine konservatif tedavi tercih edilir. Konservatif tedavi ve daha az invaziv tedavi seçenekleri uygulanması çocuk hastalarda olası riskleri azaltmak için gereklidir. Bu makalede, alt çeneye ait ölçü modeller üzerinde elde edilen splintin, mandibulayı çevreleyen tellerle fiksasyonu ile tedavi edilen iki olgu sunulmaktadır. Hastalarda splintler üç hafta süreyle tutularak tedavi edilmişlerdir.

Anahtar sözcükler: Pediatrik, mandibular kırık, circummandibular teller, akrilik splint

\section{Introduction}

Pediatric fractures are rare when compared with fractures in the adult population and is estimated to occur in $5 \%$ of all maxillofacial traumas. Boys are more commonly affected than girls and these fractures are particularly seen in children between 6 and 12 years of age. Approximately $40 \%$ of all pediatric fractures involve the mandible. When all forms of fractures are considered, childhood play is the most frequent cause of facial fractures, but because they consist of falls from low heights, play rarely causes serious injury. Motor vehicle accidents are the most common cause of serious facial fractures in children. ${ }^{1}$

In management of these fractures, the goal is to restore the underlying bony architecture to its pre-injury position in a stable fashion, with minimal aesthetic and functional impairment. ${ }^{2}$ Closed reduction techniques with maxillomandibular fixation in very young children can pose several concerns, including cooperation, compliance and adequate nutritional intake. Open reduction with rigid internal fixation (ORIF) of unstable mandibular fractures using miniplates and screws are thought to have a negative effect on skeletal growth and unerupted teeth and involve twostage surgery because of the need for plate removal after complete healing. ${ }^{3}$

Most fractures have been treated conservatively by dental splints and rubber elastics. An occlusal splint with circummandibular wires is another treatment which is a relatively simple technique for mandibular fractures in children. ${ }^{4}$ 
The aim of the present study was to report two pediatric cases of mandibular fractures that were treated using circummandibular wiring method. Informed consent forms were obtained.

\section{Case 1}

A 4-year-old girl was referred to the Department of Oral and Maxillofacial Surgery with a history of falling from stairs 3 days ago. The patient's medical history was noncontributory, and she was not under any medication. The patient was conscious but she was non-cooperative when referred to our clinic. Clinical and radiological examination showed a dislocated fracture line between lower incisors. (Figs. $1 \mathrm{a}, \mathrm{b}$ ). Treatment planning comprised fixation of the splint to the dentoalveolar structure by circummandibular wires and the patient's family was informed. Impressions of both jaws were taken with silicone impression material. A splint was constructed in the laboratory using acrylic material. The next day, under general anesthesia, the dislocated segment was replaced by bi-digital pressure with the guidance of the splint. The fixation of the acrylic splint to the dentoalveolar structure was achieved by circummandibular wires (Fig. 2). The patient was discharged without intermaxillary fixation. The antibiotic treatment consisted of sultamisilin oral suspension (three times a day, $25 \mathrm{mg} / \mathrm{kg}$ ) (Duocid, Pfizer) for 2 weeks and analgesic acetaminophen suspension (three times aday, $250 \mathrm{mg}$ ) (Calpol, GlaxoWellcome) for 1 week. Postoperative instructions for the patient included soft diet. On postoperative day 26, radiological evaluation was made and the splint was removed under sedation. The clinical evaluation after 3 months showed that both centric occlusion and healing were excellent (Figs. 3 a, b).

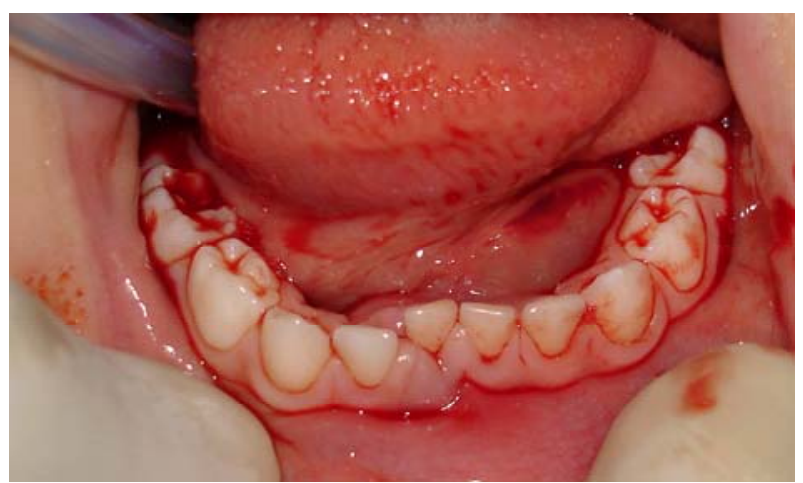

Figure 1a. Intraoperative appearance of the patient.

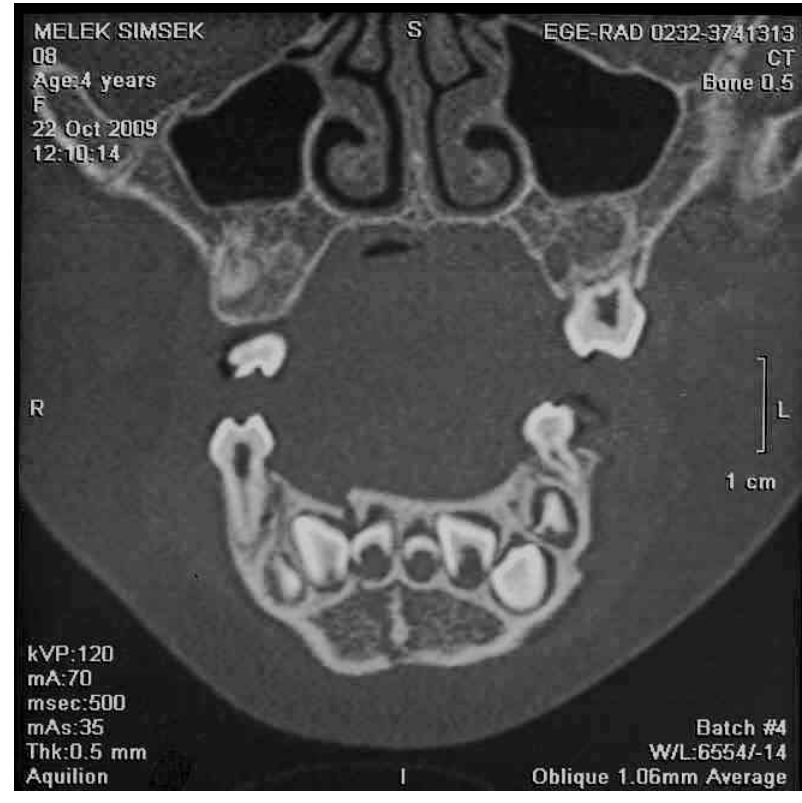

Figure 1b. Coronal CT image shows a dislocated fracture line between lower incisors.

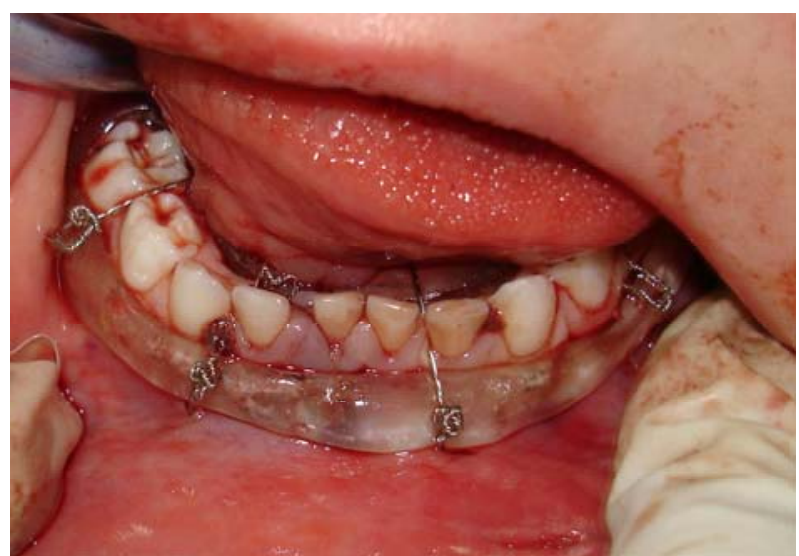

Figure 2. Mandibular stabilization using circummandibular wiring technique. 


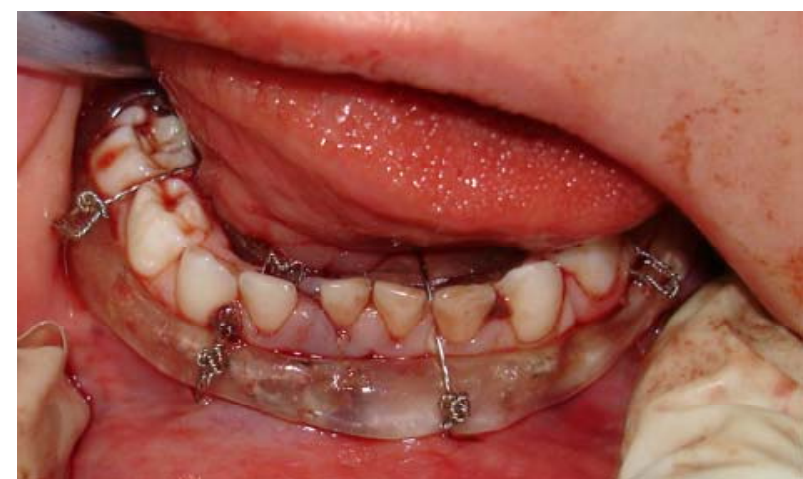

Figure 3a. Clinical view of the patient after 3 months.

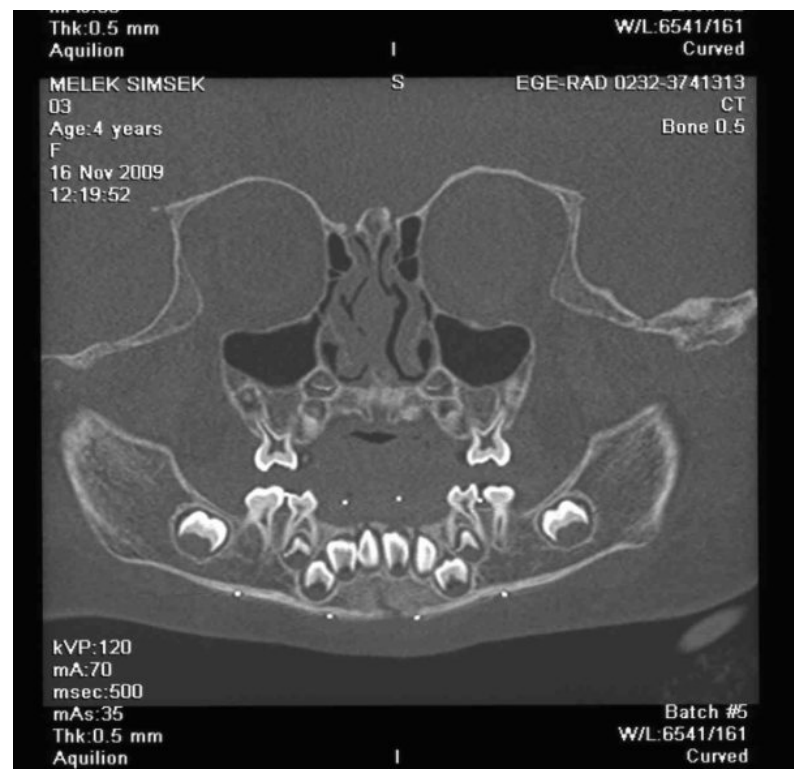

Figure 3b. Coronal CT image at 26 day follow-up of the patient.

\section{Case 2}

A 2-year-old male was referred to the Department of Oral and Maxillofacial Surgery with a history of falling. The patient's medical history was noncontributory and he was not under any medication. This patient was non-cooperative as the first patient when referred to our clinic. Radiological examination showed a vertical fracture line between lower incisors (Fig. 4). The same treatment procedure was also preferred for this patient. Under mild sedation, impressions of both jaws were taken with silicone impression material.
All procedures (Fig. 5) and the antibiotic treatment were identical for the second patient.

On postoperative day 23, after radiological evaluation the second patient's splint was removed. The clinical evaluation after 5 weeks showed that healing was excellent (Figs. 6 a, b).

Both of the patients were treated as out-patients and tolerated the treatment well. No signs of complications were observed during the healing period.

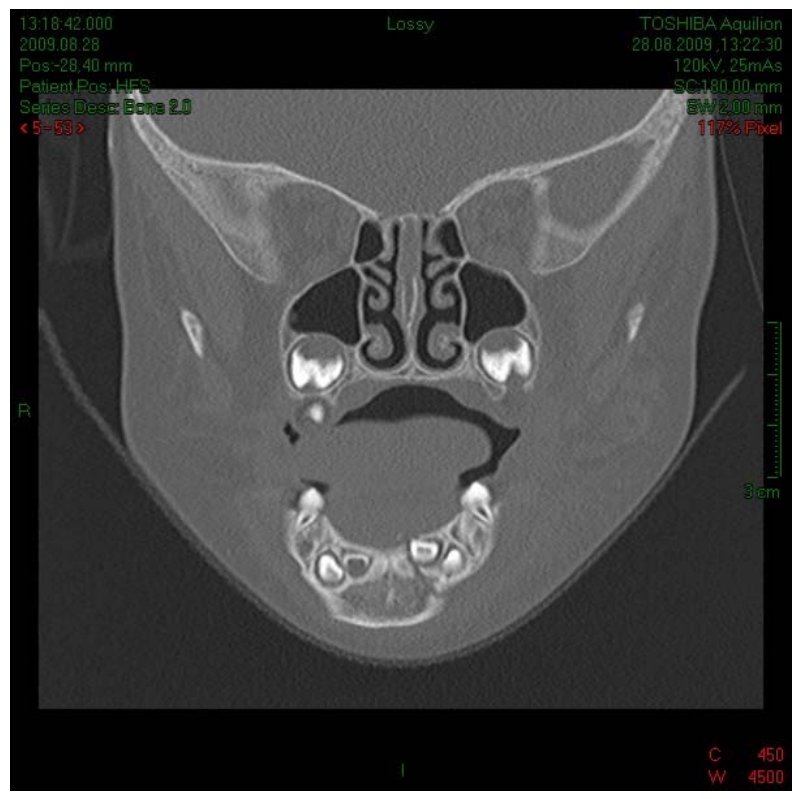

Figure 4. Coronal CT image shows a nondislocated fracture line between lower incisors.

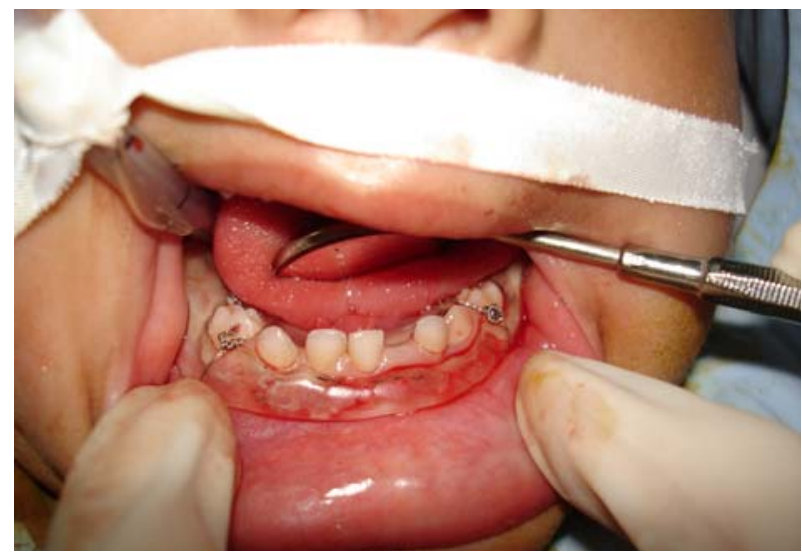

Figure 5. Mandibular stabilization using circummandibular wiring technique. 


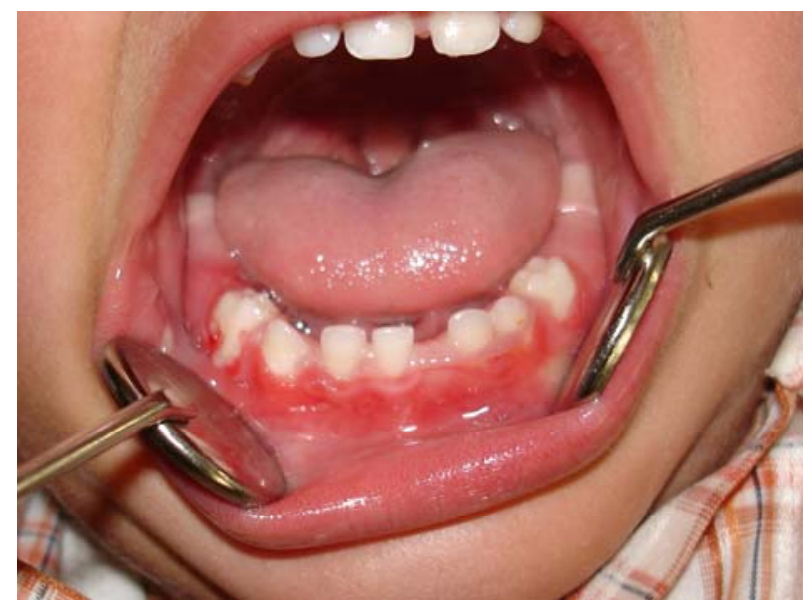

Figure 6a. Clinical view of the patient after 5 weeks.

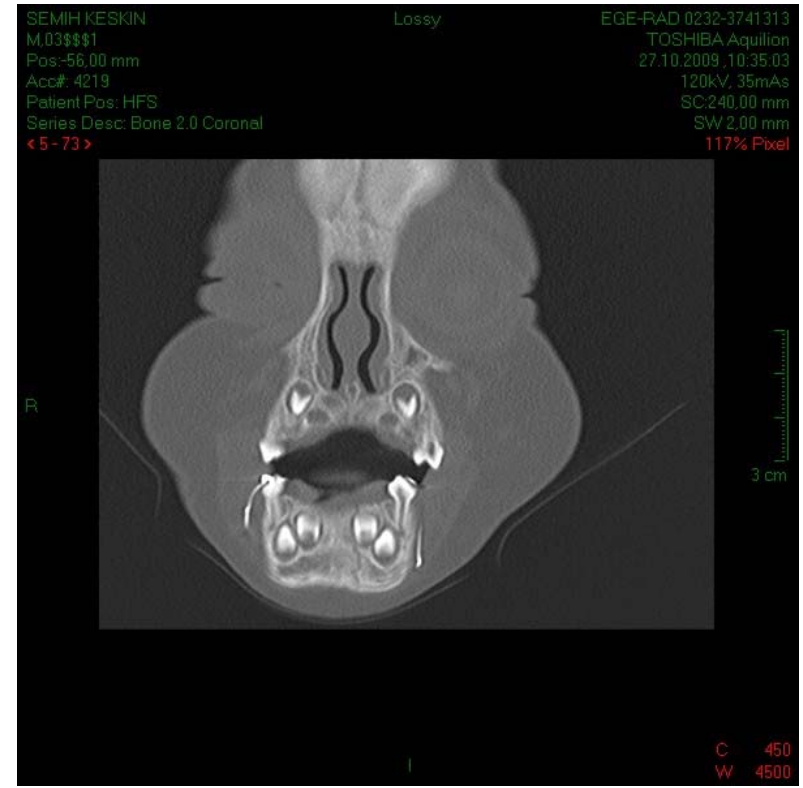

Figure 6b. Coronal CT image shows at 23 day follow-up of the patient.

\section{Discussion}

Fractures of the pediatric facial skeleton have special characteristics, and specific knowledge is necessary for their diagnosis, management, and follow-up. To understand the differences between pediatric and adult facial fracture patterns, a familiarity with the processes of facial growth and development is essential. Facial growth, paranasal sinus development, dentition, and bone structure all affect the pattern of facial fractures in children. ${ }^{5}$
Management of children with primary or mixed dentition is complicated by several factors. First is the presence of secondary, unerupted teeth in the mandible body until 6 years of age or longer. ORIF with a plate in preadolescent children places their secondary dentition at significant risk of injury, and thus only monocortical plating should be performed. Second is the difficulty of maintaining secure mandibular-maxillary fixation (MMF) when the teeth are not present or are not firmly anchored in the mandible. In most preadolescent children, MMF cannot depend on arch bars and requires lingual splints and/or circummandibular wiring. ${ }^{6}$

Although it was reported that the process of preparing lingual splints is time-consuming and exacting because dental impressions with reconstruction of the prefracture occlusion is required, ${ }^{6}$ Irby ${ }^{7}$ described the lingual splint under the category "simple splints," and recommended its use in reduction and stabilization of displaced dentoalveolar fractures in children. Operative treatment should involve minimal manipulation and may be modified because the treatment of bony injuries is most easily accomplished by techniques that may adversely affect craniofacial development in children. $^{2}$ In a clinical study, which was conducted on 7 children by Abdullah, ${ }^{8}$ it was stated that the use of one microplate with 1.5 monocortical screws at the inferior border of the mandible with a dental tension band appeared to maximize the advantages of an ORIF technique without any risk of injuring the teeth buds and without affecting the stability of the fracture fixation. Yaman et al. $^{9}$ discussed a malpractice case and recommended that screws and plates should be removed as soon as healing period is over and especially in pediatric cases, doctors must have a greater responsibility about therapy period. İçten et al. ${ }^{10}$ reported the conservative treatment of three mandibular fracture cases. These authors stated that healing of the fractures were observed within three weeks. 
In two of our cases, especially for the second case, closed reduction technique with maxillomandibular fixation could cause several problems, such as compliance and adequate nutritional intake. ORIF with a plate would entertain a risk for secondary dentition. Fixation of the splint with circummandibular wiring technique was less invasive method in comparison with ORIF technique. Circummandibular wiring technique provided efficient stability for two cases. Both of the patients tolerated the treatment well.

According to the extensive literature search, there is a limited number of articles regarding treatment of pediatric mandibular fracture with fixation of the splint by circummandibular wires. Although this treatment involved minimal operative manipulation, the technique should be applied by an experienced surgeon.

\section{Conclusion}

While the basic principles for mandibular fracture treatment are the same as for the adult, certain anatomical features of the pediatric mandible warrant special attention. For the proper treatment, mixed dentition, unerupted teeth, the shapes of teeth and ongoing growth in the mandible should be carefully considered. Although there is no clear consensus about the optimal method for fixation of mandibular fractures; effective, simplest and less invasive method is the best method.

\section{References}

1. Güven O. Fractures of the maxillofacial region in children. J Craniomaxillofac Surg 1992; 20: 244-247.
2. Schweinfurth JM, Koltai PJ. Pediatric mandibular fractures. Facial Plast Surg 1998; 14: 31-44.

3. Koltai PJ, Rabkin D, Hoehn J. Rigid fixation of facial fractures in children. $J$ Craniomaxillofac Trauma 1995; 1: 32-42.

4. Reddy BK, Bartlett SP. Pediatric Facial Fractures. Pediatric Plastic Surgery. Ed. Stamford, p.p. 46386, 1998.

5. Alcalá-Galiano A, Arribas-García IJ, Martín-Pérez MA, Romance A, Montalvo-Moreno JJ, Juncos JMM. Pediatric Facial Fractures: Children Are Not Just Small Adults. Radiographics 2008; 28: 441-461.

6. Giannoni CM. Pediatric facial trauma. In: Stewart M.G. Head, face and neck taruma: a comprehensive management. Thieme Med. Publishers, New York, p.p.150-63, 2005.

7. Irby WB. Cast and acrylic splints: their application in oral and maxillofacial surgery. In: Archer W.H. Oral and maxillofacial surgery, 5th ed. WB Saunders, Philadelphia, p.p.1364-72, 1991.

8. Abdullah WA. The use of a single titanium microplate in displaced pediatric parasymphysial mandibular fractures. Saudi Dent $J$ 2009; 21: 95-100.

9. Yaman F, Atılgan S, Erol B. Malpractise in a child with mandibular fracture: a case report. Biotechnol Biotechnol Eq 2006; 20: 185-187.

10. İçten $\mathrm{O}$, Duran $\mathrm{S}$, Tuğcu F. Treatment of mandibular fractures in children. AÜ Dişhek Fak Derg 1995; 22: 293-297.

\footnotetext{
Yazışma Adresi:

Dr. Banu ÖZVERI KOYUNCU

Ege Üniversitesi,

Diş Hekimliği Fakültesi,

Ağız, Diş, Çene Cerrahisi AD,

35100 Bornova - IZMiR

Tel : (232) 3881108

E-posta : banuozverikoyuncu@yahoo.com
} 